\title{
Hepatoprotective Effect of Thymoquinone Against Cadmium Induced Liver Toxicity in Wistar Rat by Inhibiting Reactive Oxygen Species
}

\author{
Mohammad Firoz Alam ${ }^{*}$, Yakoob Khormi ${ }^{2,}$ Abed Khairat Alkhairat ${ }^{2,3}$ and Abdullah Mohammed Ahmed Qahl ${ }^{2,4}$ \\ ${ }^{1}$ Department of Pharmacology and Toxicology, Jazan University, Kingdom of Saudi Arabia
}

${ }^{2}$ College of Pharmacy, Jazan University, Kingdom of Saudi Arabia

${ }^{3}$ Pharmaceutical Care Department, Prince Mohammed Bin Nasser Hospital, Saudi Arabia

${ }^{4}$ Department of Pharmacy, Imma Abdulrhman bin Faisal Hospital, Kingdom of Saudi Arabia

Submission: September 26, 2018; Published: November 27, 2018

"Corresponding author: Mohammad Firoz Alam, Assistant Professor, Department of Pharmacology and Toxicology, College of Pharmacy, Jazan University, Jazan, Kingdom of Saudi Arabia

\begin{abstract}
The present study was designed to find out the hepatoprotective effect of Thymoquinone against cadmium induced liver toxicity in rat. Four different groups of rats were used for this study. In details Group-I was nornal rat; Group-II was toxic Cd ( $2 \mathrm{mg} / \mathrm{kg} / \mathrm{day})$ has given to rats subcutaneously for 7 days. Group-III was pre-treated with Thymoquinone and followed by Cd $(2 \mathrm{mg} / \mathrm{kg} / \mathrm{day})$ for 7 days. Group-IV was given Thymoquinone $(20 \mathrm{mg} / \mathrm{kg} /$ day) as a positive control for 7 days. At the end of experiment blood was taken for biochemical study (AST, ALT, ALP and Total Bilirubin) and thereafter animal was killed, and liver was dissected out to analyze oxidative stress (LPO, and GSH). The biochemical study indicated that the level of enzymes (AST, ALT, ALP and Total Bilirubin) was significantly ( $\mathrm{P} \leq 0.01$ ) elevated in the serum of Group-II and TBARS contents were also increased significantly in Group-II while the concentration of glutathione was significantly reduced in Cd induced (Group-II) as compared to normal control. When the rat was treated with Thymoquinone, TBARS content reduced significantly in Group-III and biochemical enzyme were also restored in Group-III while the glutathione (GSH) content increased as compared to Group-II. When alone Thymoquinone was given in Group-IV there was no any kind of biochemical enzyme elevation were found or neither no significant oxidative stress observed. In this way study indicated that Thymoquinone is effective for the treatment of liver diseases against heavy metal.
\end{abstract}

Keywords: Cadmium chloride; Hepatotoxicity; Thymoquinone; Rats; Liver diseases; Heavy metal; Natural medicine; Ranunculaceae; Illness; Death; Liver tonic; Diuretic; Anti-diabetic; Anti diarrheal; Antibacterial; Antihypertensive; Anti-inflammatory; Antioxidant properties

Abbreviations: TQ: Thymoquinone; ALT: Alanine Aminotransferase; AST: Aspertate Aminotransferase; ALP: Alkaline Phosphatase; PMS: Post Mitochondrial Supernatant; TBARS: Thiobarbituric Acid Reactive Substance

\section{Introduction}

The use of natural medicine has markedly increased over the last few years due to its lesser side effects. Nigella sativa commonly known as black seed belongs to the family Ranunculaceae. The name Nigella is an Arabic consent "Habbat al-barakah" means the seed of blessing. Prophet Muhammed (S.A.S) quoted the importance of black seed and stated that "Black seed has a remedy for every illness except death [1]. Thymoquinone (TQ) is the active ingredient of Nigella sativa seed oil. Traditionally it is used as liver tonic, diuretic, anti-diabetic, anti-diarrheal, antibacterial, antihypertensive, anti-inflammatory, an antioxidant properties $[2,3]$. Previous study indicated the versatile pharmacological activities such as hepatoprotective. In recent study, antioxidant and anti-inflammatory cytokine of TQ studies were carried out by Alam et al., [4]. Liver is one of the most targeted vital metabolic organs which responsible to metabolite the various kinds of drug and chemicals.

The liver generally metabolite the highly toxic chemical to non-toxic chemical but some time it also activates the non or less toxic to high toxic metabolite. Therefore, the burden of chemicals increases the stress on hepatic cell and resulted in hepatic disorder by degenerative cell, necrosis and tumors etc. [5]. Cadmium poisoning is one of the global health problems that affect many organs, and in some cases, it causes death. Worldwide cadmium production, consumption and release into the environment without proper treatment resulted in the contamination of air, water and soil. The long-term exposure to cadmium through water, air, and food system leads to various organ problem to cancer problem [6]. Cadmium is one of the heavy metals, which is 
highly toxic, which is used in various forms in chemicals (pigment, coating) and metallurgical (metal alloys) industry [7]. Many researches have proven its hepatotoxic nature by administration of Cadmium chloride to rat that produces cell necrosis and fatty changes [8]. The development of necrosis is directly associated with leakage of hepatic enzyme into serum. Thus, there is need to investigate the hepatoprotective effect of TQ against cadmium induced liver toxicity in rats which is still not reported.

\section{Material and Methods}

\section{Chemicals}

Thymoquinone, Cadmium chloride, Trichloroaceticacid, 2-thiobarbituric acid,1-sulfosalicylic acid, Hydrogen peroxide and DTNB were purchased from Sigma Aldrich USA. Biochemical Assay kits Alanine aminotransferase (ALT), Aspertate aminotransferase (AST), Alkaline phosphatase (ALP) and Bilirubin were procured from Humans for biochemical and Diagnostic, Germany.

\section{Experimental design}

The male rat $(200 \mathrm{~g})$ was taken from the animal house of Jazan University for the study. All animals were kept in the lab for acclimatization before starting the experiments. Animal handling and experiment were performed after approval of ethical committee as per International and Islamic Laws perspective [9]. Rats were divided into 4 groups, each having 6 rats. Four different groups of rats were used for this study. In details Group-I was normal rat; Group-II was toxic $\mathrm{Cd}\left(2 \mathrm{mg} / \mathrm{kg} /\right.$ day as $\left.\mathrm{CdCl}_{2}\right)$ has given to rats subcutaneously for 7 days; Group-III was pre-treated with Thymoquinone and followed by $\mathrm{Cd}\left(2 \mathrm{mg} / \mathrm{kg} /\right.$ day as $\left.\mathrm{CdCl}_{2}\right)$ for 7 days [10]. Group-IV was given Thymoquinone $(20 \mathrm{mg} / \mathrm{kg})$ as a positive control [11].

\section{Biochemical estimation}

At the end of experiment blood was collected from orbital puncture of rat immediately for biochemical estimation. In brief, the collected blood sample was kept at room temperature for $30 \mathrm{~min}$ and then centrifuged at $3000 \mathrm{rpm}$ for $10 \mathrm{~min}$ to isolate

\section{Results}

\section{Effects of thymoquinone on serum marker}

Table 1: Effects of Thymoquinone on biochemical parameter.

\begin{tabular}{|c|c|c|c|c|}
\hline Biochemical Enzymes & Group-I (Control) & Group-II (CdCl2) & Group-III (CdCl2+TQ) & Group-IV (TQ) \\
\hline AST (u/l) & $21.3 \pm 1.72$ & $72.65 \pm 2.47^{*} \mathrm{p} \leq 0.05$ & $22.75 \pm 3.21 \mathrm{NS}$ \\
\hline ALT (u/l) & $11.4 \pm 1.13$ & $28.45 \pm 3.67^{* *} \mathrm{p} \leq 0.01$ & $14.72 \pm 2.30{ }^{\# \#} \mathrm{p} \leq 0.05$ \\
\hline ALP (mg/dl) & $253.22 \pm 12.81$ & $743.21 \pm 16.09 * \mathrm{p} \leq 0.05$ & $338.85 \pm 20.32 \mathrm{NS}$ \\
\hline Total Bilirubin (mg/dl) & $0.55 \pm 0.13$ & $0.82 \pm 0.041^{* * *} \mathrm{p} \leq 0.001$ & $0.6 \pm 0.10$ \#\#\# $\mathrm{p} \leq 0.001$ \\
\hline
\end{tabular}

Data represents mean \pm SD $(n=6) ;{ }^{*} p<0.05,{ }^{* *} p<0.01{ }^{* * *} p<0.001$ vs Group-I; ${ }^{*} p \leq 0.05$, ${ }^{\#} p \leq 0.01$, \#\#\# $\leq 0.001$ vs Group-II; NS: not significant

The level of biochemical enzyme such as AST, ALT, ALP and Total Bilirubin was significantly increased in cadmium treated Group-II as compared to control Group-I. While the concentration of AST, ALT, ALP and Total Bilirubin were significantly reduced in Group-III in treating with Thymoquinone as compared to Group-II. There were no significant changes found in Group-IV as compared to normal control (Table 1). the serum. Further, serum was preserved at $-20^{\circ} \mathrm{C}$ for further biochemical analysis of liver function test. Thereafter, the animal was a further sacrifice by cervical dislocation and liver tissue was isolated for oxidative stress analysis.

\section{Tissue homogenate preparation}

Isolated liver was homogenized in phosphate buffer $(0.01 \mathrm{M}$, $\mathrm{pH} 7.0)$ to give a $10 \%(\mathrm{w} / \mathrm{v})$ homogeneous and it was further centrifuged at 3,000 RPM for $15 \mathrm{~min}$ at $4^{\circ} \mathrm{C}$ to isolate the supernatant (S1) for lipid peroxidation (TBARS) test. The aliquot obtained was further centrifuged at $12,000 \mathrm{~g}$ for $20 \mathrm{~min}$ at $4^{\circ} \mathrm{C}$ to get post mitochondrial supernatant (PMS) for the test of glutathione (GSH).

\section{TBARS}

Thiobarbituric Acid Reactive Substance (TBARS) contents were carried out by Utley et al., [12] and modified by Islam et al procedure [13]. In details two samples of supernatant each having $0.5 \mathrm{ml}$ was incubated at $37 \pm 1^{\circ} \mathrm{C}$ in a metabolic shaker $(120$ cycles/ min) and another $0.5 \mathrm{ml}$ was placed at $0^{\circ} \mathrm{C}$ for $60 \mathrm{~min}$. After 1 hour of incubation, $1 \mathrm{ml}$ of $10 \%$ chilled TCA, $1 \mathrm{ml}$ of $0.67 \%$ TBA and $0.5 \mathrm{ml}$ phosphate buffer was added to each sample and mixed after each addition. The aliquot from each vial was centrifuged at 4,000 RPM for $10 \mathrm{~min}$. Thereafter, supernatant was transferred to another tube and placed in the boiling water bath. After $20 \mathrm{~min}$, the test tubes were cooled, and the observance of the color was read at $535 \mathrm{~nm}$.

\section{Reduced glutathione (GSH)}

Reduced glutathione (GSH) was estimated by Jollow et al. Post Mitochondrial Supernatant (PMS) was mixed with $4 \%$ sulfosalicylic acid in a ratio of $1: 1$ and then samples were incubated at $4^{\circ} \mathrm{C}$ for $1 \mathrm{~h}$. After the incubation the reaction mixture was centrifuged at $3000 \mathrm{RPM}$ for $15 \mathrm{~min}$ at $4^{\circ} \mathrm{C}$ and the supernatant was used for observance of color at $412 \mathrm{~nm}[14]$.

\section{Estimation of protein:}

Lowry et al. [15] method was used for estimation of protein in the liver homogenates. 


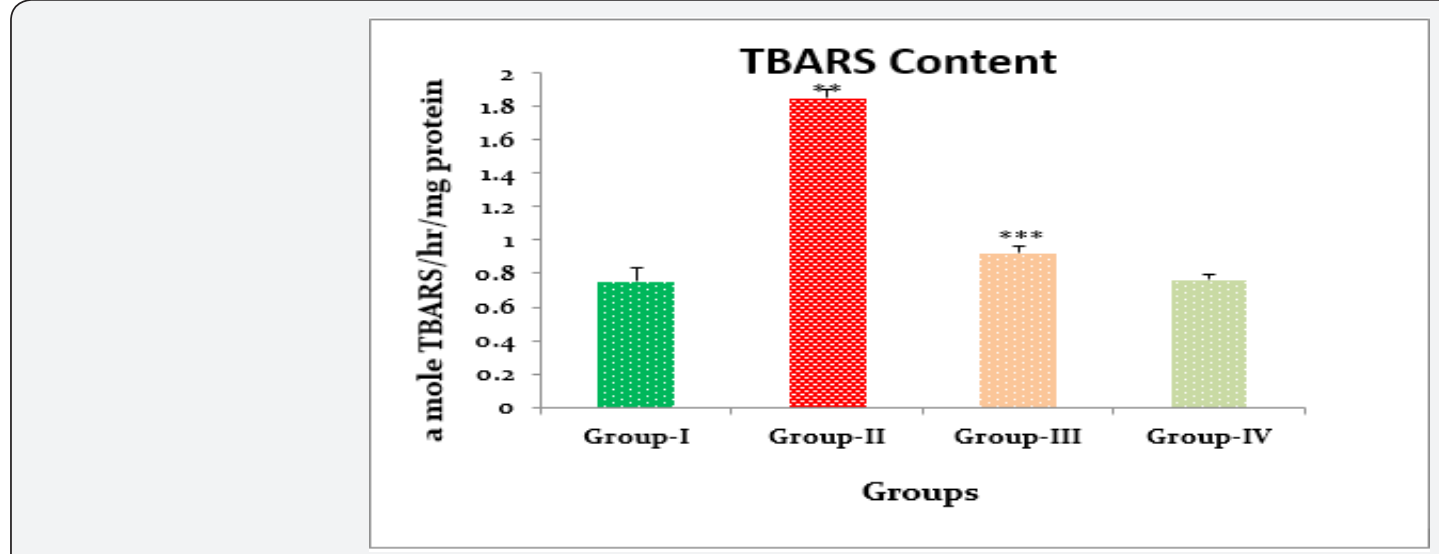

Figure 1: Effects of Thymoquinone on Lipid per oxidation test (TBARS) in rat liver tissue.

Data represents mean \pm S.E.M $(n=6)$. Unit of LPO are nmoles of TBARS/hr/mg protein. ${ }^{* *} p<0.01$ Group-II vs Group-I, ${ }^{* * *} p<0.001 \mathrm{Group}-$ III Vs Group-II

\section{Effects of thymoquinone on GSH}

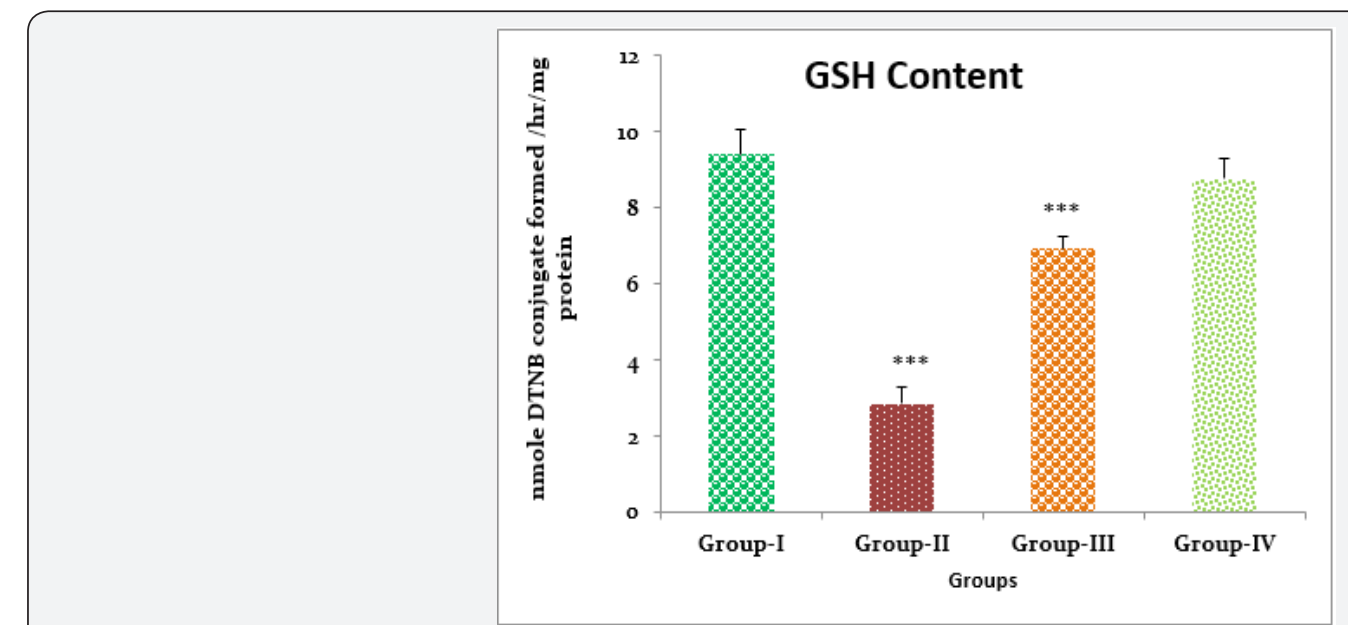

Figure 2: Effects of Thymoquinone on Glutathion test (GSH) in rat liver tissue.

Values is represented in mean \pm S.E. $(n=6)$. Unit of GSH is expressed as nmole DTNB conjugate formed $/ \mathrm{hr} / \mathrm{mg}$ protein. ${ }^{* * *} \mathrm{p}<0.001 \mathrm{Group}-$ II vs Group-I; **p<0.001 Group-III vs. Group-II.

Figure 2 shows the content of glutathione (GSH) was decreased in Cd treated Group-II as compared to control Group-I. Thymoquinone increased the GSH content in Group-III as compared to Group-II while there were not significant changes monitored in Group-IV as compared to Group-I.

\section{Discussion}

The important and largest organ of the body is the liver which plays an important role in chemical detoxification. Any change in their liver function parameters may affect the functioning of the body as well as bad consequences of the health. The present study indicated the significant elevation of blood serum markers such as AST, ALT, ALP and Biluribin in cadmium induced GroupII when compared to normal control Group-I. But the treatment with TQ all serum marker enzyme elevations reduced significantly in Group-III. Cadmium also increases the lipid peroxidation (TBARS) in hepatic cell in Group-II but when it was treated with TQ dramatically reduced the elevation of TBARS content in the hepatic cell in Group-III.
Many studies have shown that $\mathrm{Cd}$ induces hepatocellular damage due to imbalance of cellular redox status which leads to oxidative stress. Recently administration of Naringenin at a dose of $(50 \mathrm{mg} / \mathrm{kg})$ significantly reversed the activities of serum hepatic marker enzymes in their normal levels when compared to Cdtreated rats. In addition, Naringenin significantly reduced lipid peroxidation and restored the levels of antioxidant defense in the liver [16]. In this study cadmium also significantly ( $\mathrm{p} \leq 0.001)$ depleted the reduced glutathione (GSH) content in the hepatic cell in Group-II and it was also recovered from the treatment of Thymoquinone. Several mechanisms have been postulated for the Cd induced hepatotoxicity through associated with sulfhyryl group binding, implicating membrane proteins and enzymes. As we know that $\mathrm{Cd}$ is non-redox metal that can indirectly cause oxidative stress by depleting GSH level in hepatic cell [17]. Glutathion is considered to be the first line of defense against oxidative damage and free radical generation [18]. Complex formation between heavy metal ion and GSH has been implicated as the initial step in biological detoxification processes, prior to 
transfer of the heavy metal to cysteine rich peptides resulted in balancing the redox cycle of glutathione. The capacity of GSH is regenerate the most important antioxidant by auto redox reaction state of the GSSG/2GSH.

Thus, Cd induced loss of GSH and indicating the disruption of the cellular GSH system which play a key role in the mechanism of Cd-induced liver damage [18-20]. Overall Thymoquinone showed a significant role to manage the reduced glutathione (GSH) in Group-III. Further deep research is needed to figure out the complete mechanism of hepatocellular damage induced by the Cadmium through understanding the different mechanistic approach such as other detailed parameter of oxidative stress, interleukin, apoptosis a mitochondrial involvement etc.

\section{Conclusion}

The present study clearly indicated that Thymoquinone suppresses the reactive oxygen species and resulted in the minimizing of the biochemical and oxidative stress parameter against Cadmium induced hepatotoxicity. There is further needing to explore the study with molecular level.

\section{Acknowledgment}

We are thankful to the Dean of the Faculty of Pharmacy, Jazan University for his encouragement and providing laboratory facilities for the student project.

\section{References}

1. Mohammed M Safhia, Mohammad Firoz Alama, SM Sivakumarb, Aamena Jabeenb, Tarique Anwera, et al. (2014) Antibacterial spectrum of black seed oil against selected human pathogenic bacteria. Journal of Pharmacy Research 8(11): 1726-1728.

2. Ahmad S, Beg ZH (2013) Hypolipidemic and antioxidant activities of thymoquinone and limonene in atherogenic suspension fed rats. Food Chem 138(2-3): 1116-1124.

3. Darakhshan S, Bidmeshki Pour A, Hosseinzadeh Colagar A, Sisakhtnezhad S (2015) Thymoquinone and its therapeutic potentials. Pharmacol Res 95-96: 138-158.

4. Mohammad Firoz Alam, Gyas Khan, Mohammed M Safhi, Sayeed Alshahrani, Rahimullah Siddiqui, et al. (2018) Thymoquinone ameliorates doxorubicin induced cardiotoxicity in Swiss albino mice by modulating oxidative damage and cellular inflammation. Cardiology Research and Practice.

5. Mohammad Firoz Alam (2018) Advancement of Nanomedicine and Targeted Drug Delivery in Perspective of Liver Disease. Advanced Research in Gastroenterology and Hepatology 9(3).

6. Mehrdad Rafati Rahimzadeh, Mehravar Rafati Rahimzadeh, Sohrab Kazemi, Ali-Akbar Moghadamnia (2017) Cadmium toxicity and treatment: An update. Caspian J Intern Med 8(3): 135-145.
7. Hart BA (2000) Response of the respiratory tract to cadmium. In: Zalpus. RK, Koropatnick J, (Eds,) Molecular Biology and toxicology of metals. London. UK: Taylor and Francis, pp. 208-233.

8. IM Alhazza (2008) Cadmium induced hepatotoxicity and oxidative stress in Rats: protection by selenium. Research Journal of Environmental Science 2(4): 305-309.

9. Naderi MM, Akhondi MM (2012) Regulations and Ethical Considerations in Animal Experiments: International Laws and Islamic Perspectives. Avicenna J Med Biotechnol 4(3): 114-120.

10. Mohammed M Safhi, Gulrana Khuwaja, Mohammad Firoz Alam, Sohail Hussain, Mohammed Abdul Hakeem Siddiqui, et al. (2016) CadmiumInduced Nephrotoxicity Via Oxidative Stress in Male Wistar Rats and Capsaicin Protects Its Toxicity. Bulletin of Environment Pharmacology and Life Sciences 5(3): 5-11.

11. Mohammed MSafhi, Qumayri Haitham M, Masmali Ammar UM, Siddiqui, Rahimullah, Alam Mohammad Firoz, et al. (2018) Thymoquinone and fluoxetine alleviate depression via attenuating oxidative damage and inflammatory markers in type 2 diabetic rats. Arch Physiol Biochem $1-6$.

12. Utley HC, Bernheim F, Hochslein P (1967) Effect of sulfhydryl reagent on peroxidation in microsome. Arch Biochem Biophys 118(1): 29-32.

13. Islam F, Zia S, Sayeed I, Zafar KS, Ahmad AS (2002) Selenium-induced alteration on lipids, lipid peroxidation and thiol group in circadian rhythm centers of rat. Biol Trace Elem Res 90(1-3): 203-214.

14. Jollow DJ, Mitchell JR, Zampagloine N, Gillete JR (1974) Bromobenzeneinduced liver necrosis: protective role of glutathione and evidence for 3,4 bromobenzeneoxide as the hepatotoxic metabolite. Pharmacol 11(3): 151-169.

15. Lowry OH, Rosebrought NJ, Farr AL, Randal RJ (1951) Protein measurement with Folin phenol reagent. J Biol Chem 193: 265-275.

16. Renugadevi J, Prabu SM (2010) Cadmium-induced hepatotoxicity in rats and the protective effect of naringenin. Exp Toxicol Pathol 62(2):171-181.

17. Martelli A, Rousselet E, Dycke C, Bouron A, Moulis JM (2006) Cadmium toxicity in animal cells by interference with essential metals. Biochimie 88(11): 1807-1814

18. Masella R, Benedetto Di, Vari R, Filesi C, Giovannini C (2005) Novel mechanisms of natural antioxidant compounds in biological systems: involvement of glutathione and glutathione-related enzymes. J Nutr Biochem 16(10): 577-586.

19. Gebhardt R (2009) Prevention of cadmium-induced toxicity in liverderived cells by the combination preparation Hepeel. Environ Toxicol Pharm 27(3): 402-409.

20. Mohammad Firoz Alam, Mohammed M Safhi, Tarique Anwer, F Islam, Siva Kumar (2017) Therapeutic action mechanism of zingerone against $\mathrm{CCl}_{4}$ induced liver mitochondrial toxicity in Swiss Albino mice. $4^{\text {th }}$ International Conference on Hepatology April 27-28, 2017 Dubai, UAE. J Liver 6: 2. 
Your next submission with JuniperPublishers will reach you the below assets

- Quality Editorial service

- Swift Peer Review

- Reprints availability

- E-prints Service

- Manuscript Podcast for convenient understanding

- Global attainment for your research

- Manuscript accessibility in different formats

( Pdf, E-pub, Full Text, audio)

- Unceasing customer service

Track the below URL for one-step submission https://juniperpublishers.com/online-submission.php 